\title{
Studies on algal carotenoids
}

\author{
Synnøve Liaaen-Jensen \\ Organic Chemistry Laboratories, Norwegian Institute of Technology, University of \\ Trondheim-NTH, N-7034 Trondheim,NTH, Norway

\begin{abstract}
Selected examples are given of recent structural studies on algal carotenoids. Interdisiplinary aspects such as algal chemosystematics and food
\end{abstract} \\ chain studies are exemplified.
}

\section{INTRODUCTION}

of the ca. 580 structurally defined naturally occurring carotenoids (ref. 1) around 100 are encountered in algae. Interdisiplinary aspects such as chemosystematics, functional aspects and food chain relations have been a special challenge for structural studies on algal carotenoids.

\section{CHEMOSYSTEMATICS}

Algal carotenoids are usually $\mathrm{C}_{40^{-}}$-skeletal. Dinoflagellates also synthesize $\mathrm{C}_{37}$ norcarotenoids. Characteristic end groups of algal carotenoid are given in Scheme 1. carotenoids are recognized as usuful chemosystematics markers for algae (Table 1).

\section{Scheme 1}

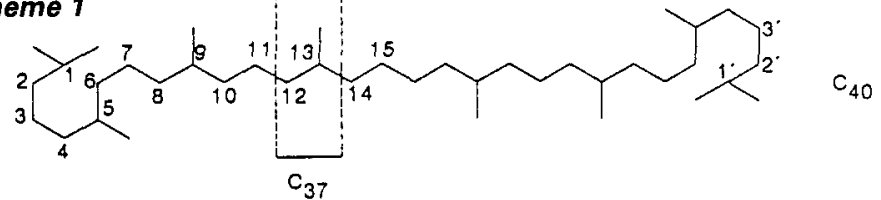<smiles>CO[C@H](/C=C/C(C)=O)C(C)(C)O</smiles><smiles>[Y]C=CC1C(C)=C[C@H](O)CC1(C)C</smiles><smiles>[Y]C=CC1=C(C)CC(O)CC1(C)C</smiles><smiles>C/C=C\C1C(C)CC(O)CC1(C)C</smiles><smiles>C/C=C/C1=C(C)C(=O)CCC1(C)C</smiles><smiles>CC(C)C1CC1(C)C1C(C)CC(O)CC1(C)O</smiles>

1<smiles>CC1=C(C)C(=CC(C)C)C(C)(C)CC(O)C1</smiles>

h<smiles>C=C(C)C(=O)CC1(C)C(C)(C)CC(O)C(I)C1(C)C</smiles><smiles>C/C=C\C1(O)CC(O)C[C@]1(C)O</smiles>

TABLE 1. Characteristic structural features of the major carotenoids of the various algal classes.

ALGAL CLASS STRUCTURAL FEATURES OF MAJOR CAROTENOIDS

Cyanophyceae Rhodophyceae Cryptophyceae Eustigmatophyceae Xanthophyceae Raphidophyceae I Dinophyceae II Prymnesiophyceae Bacillariophyceae Chrysophyceae Phaeophyceae Euglenophyceae Prasinophyceae Chlorophyceae

a) monocyclic glycosides,b)dicyclic xanthophylls,c) 4-keto, d) 6 -rings,e) 5,6 -epoxides, f) allenes, g) acetates, $h$ )acetylenic, i ) 8 -keto, j) 5,6 -diol, k) 19 -acyloxy, i) $c_{37}$-skeletal, m) $2-0 \mathrm{H}$. 


\section{STRUCTURAL STUDIES}

Examples are given on recent structural studies on algal carotenoids carried out in our laboratory.

Peridinin (1, Scheme 2 ) is the prototype of $\mathrm{C}_{37}$-skeletal carotenoids. Recent complete ${ }^{1} \mathrm{H}$ NMR assignments confirm the structure. Three z-isomers obtained upon iodine catalyzed stereomutation have been assigned 9-cis, $13^{\prime}$-cis and $11^{\prime}, 13^{\prime}$-dicis configuration by ${ }^{1} \mathrm{H}$ NMR. The butenolide structural element was recently also encountered in a new $\mathrm{C}_{40}$-carotenoid uriolide (2) from a prasinophyte (ref. 2).

The structure of the first naturally occurring oxabicyloheptane carotenoid eutreptiellanone (3) is discussed, as well as related 3,6-oxabicycloheptane derivatives (refs. 3,4). In vitro formation of 2,5-oxabicycloheptane carotenoids from caroten-2-ols with $\mathrm{BF}_{3}$ is referred to (ref. 5).

Spectroscopic and chemical evidence for the novel $\mathrm{c}_{4} 0^{-k e t o c a r o t e n o i d s ~ p r a s i n o x a n t h i n(}(\underline{4})$ and dihydroprasinoxanthin epoxide (ㅁ) are treated in some detail (refs. 6,2).

New allenic $\mathrm{C}_{40}$-ketocarotenoids are the naturally occurring fucoxanthin( 6 ) derivatives 191hexanoyloxyfucoxanthin (ref. 7) and 19'-butanoyloxyfucoxanthin (6a). HPLC and 2D $1_{H}$ NMR data are given.

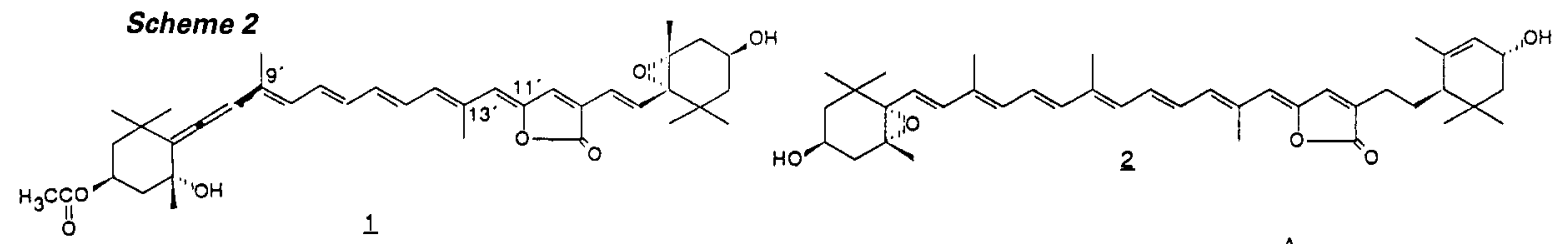<smiles>CC1=C(C#C/C(C)=C/C=C/C(C)=C/C=C/C=C(C)/C=C/C=C(C)/C=C/C23CC(CC2=O)C(C)(C)C3)C(C)(C)CC=C1</smiles><smiles>C=C(C=CC(C)=CC=CC=CC(C)=CC=CC(C)=C(C)C[C@@]1(O)C(=C)C[C@@H](O)CC1(C)C)C=CC1C(C)=C[C@H](O)CC1(C)C</smiles><smiles>C=C(C)CCC1C(C)(C)C[C@@H](O)C[C@]1(C)O</smiles>

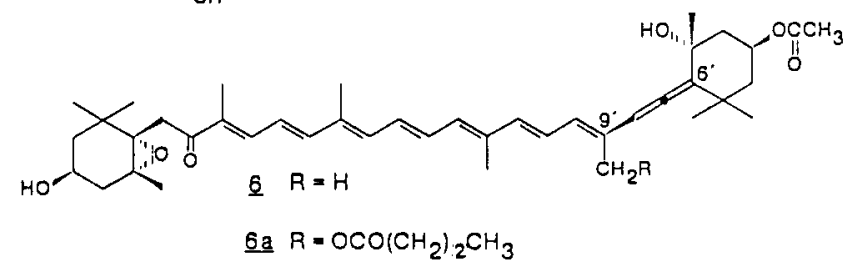

optical isomerism is possible for allenic carotenoids such as $\underline{6}$. By analogy with the stereospecific, photosensitized oxidation of a chiral cyclohexenol reported by Isoe et al. (ref. 8), it has been suggested that (6's)-fucoxanthin was the biosynthetic precursor of the more stable (6'R)-isomer (6) (ref, 8). The formation of (6's)-fucoxanthin upon iodine catalyzed stereomutation (ref. 9 ) is peing disproved. Detailed ${ }^{1} \mathrm{H}$ MMR ROESY (rotating frame NOE) experiments for all-trans 6 a and $91-c i s$ 6a in collaboration with Englert suggest that $\left(\sigma^{\prime} \underline{R}\right)$-g'cis-fucoxanthin has been misidentified as all-trans-(6'ㅗ). CD data are supportive.

$\left(6 \underline{S}, 6^{\prime} \underline{S}\right)-\epsilon, \epsilon$-Carotene $(7$, Scheme 3$)$, isolated from a chrysophyte, possesses negative cotton effect and is the first example of an algal carotenoid with (6ㅇ)-configurated $\epsilon$-end group.

All-trans carotenoids are usually the naturally occurring geometrical isomer with few classical exceptions. Recently we have demonstrated that 9 -cis-neoxanthin is the naturally occurring isomer in green leaves, spinach and the algae studied. In solution g'-cis is gradually converted to all-trans (

New algal acetylenic carotenoids from Euglenophyceae include the highly unsaturated carotene 9. The chirality we had previously assigned to hetereoxanthin has been reversed by Eugsters group at $c-5,6$ to 10 (ref. 10 ).

Gyroxanthin from dinoflageliates is the first known allenic, acetylenic carotenoid. Also the acetylenic, epoxidic end group represents a new structural feature. Gyroxanthin occurs as a natural diester (1ㅡ). spectroscopic data including COSY ${ }_{\mathrm{H} \text { NMR }}$ are given. 
Scheme 3<smiles>CCCC=CC(C)=CC=CC(C)=CC=CC=CC(C)=CC=CC=CC1C(C)=CCCC1(C)C</smiles>

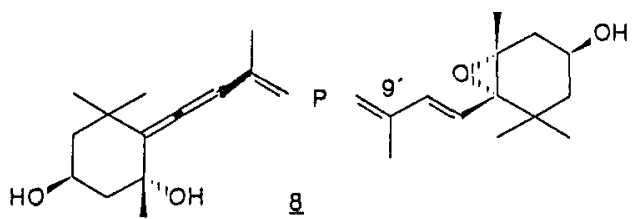

$\underline{8}$<smiles>C=C(C)C#CC1=C(C)C=CCC1(C)C#CC(=C)C</smiles><smiles>C=C(C)C#CC1=C(C)CC(O)CC1(C)C</smiles>

10

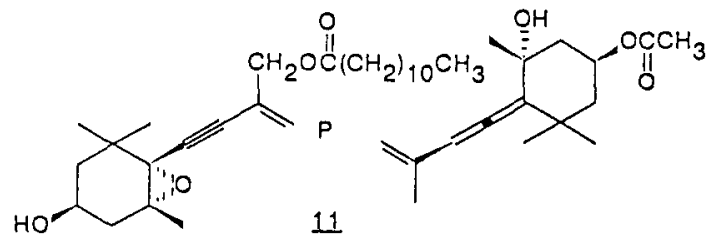

Blue-green alga (cyanobacteria) produce sec., allylic glycosidic carotenoids derived from the hypothetical aglycones myxol (12, scheme 4) of known (ref. 11), and oscillol (13) of tentative chirality. In a recent reinvestigation the sugar moiety bound to $\frac{12}{12}$ in oscillatoria agardhi 1 was shown to be $\alpha$-linked chivonose $(14)$ and the 0 -methyl methylpentose bound to $\underline{12}$ in $\underline{0}$. bornetti to be $\alpha$-linked 3-0-methyl-fucose (15) (ref. 12).

currently a carotenold tetra (?) saccharide P457 from dinoflagellates is being studied.

\section{Scheme 4}

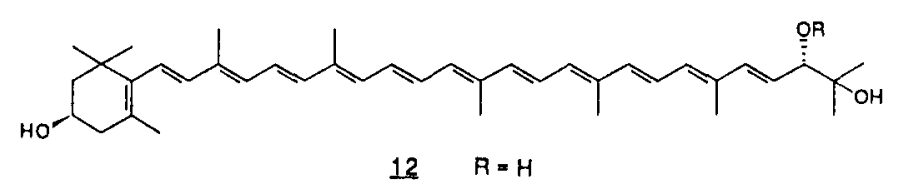

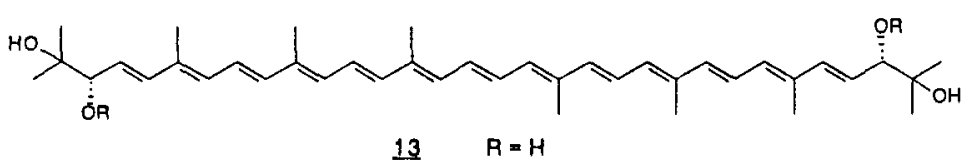<smiles>C[C@H]1O[C@@H](O)[C@H](O)[C@H](O)[C@H]1O</smiles>

14

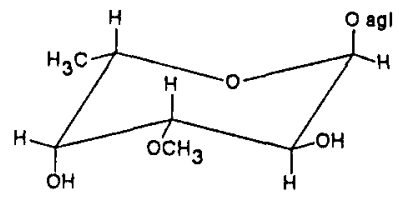

15

\section{FOOD CHAIN STUDIES}

Carotenoids are synthetized de novo by algae, which represent the bottom of the marine food chain. Carotenoids are selectively resorbed and metabolized along the food chain.

Sulfated carotenoids, the bastaxanthins, including bastaxanthin $\subseteq$ ( 16 , Scheme 5 ), possess cyclopentanone rings. Isolated from a marine sponge they are likely metabolic products of microalgal, dietary diadinoxanthin (17) (ref. 13).

Experimentally documented is the selective resorption of $\beta, \beta$-carotene (19) from a green alga by the zooplankton Daphnia magna, and the metabolic transformation to new (2R)-2hydroxy-4-keto-carotenoids (20) (ref. 14).

Selective resorption of fucoxanthin (6), 19'-hexanoyloxyfucoxanthin, diadinoxanthin (17) and peridinin ( $1, c_{37}$-skeletal) from algal unicultures by Mytilus edulis (edible mussel), and metabolic transformations of the carotenoids resorbed, have recently been studied. Twenty different carotenoids, including three new metabolites, anhydro-amarouciaxanthin $\underline{B}$ (21), 19'-hexanoyloxyisomytiloxanthin (22) and hydrato-pyrrhoxanthinol (23), have been structurally identified. General metabolic reactions included hydrolysis of carotenoid acetates, conversion of allenic $(\underline{24})$ to acetylenic (25) end groups and transformation of 5,6 -epoxides $(\underline{25})$ to 5,6 -glycols $(\underline{27})$. 


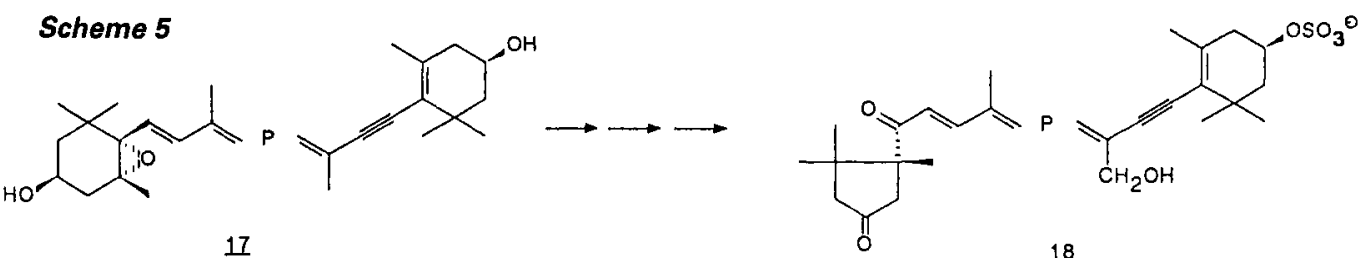

17<smiles>[X]C1=C(C)CCCC1(C)C</smiles>

19<smiles>CC1=C(C)C(C)(C)C(O)CC1=O</smiles>

20<smiles>C=C(C)C=C1C(C)(C)CC(OC)C[C@]1(C)O</smiles>

24<smiles>CC1=C(C#CC(C)C)C(C)(C)CC(O)C1</smiles>

25

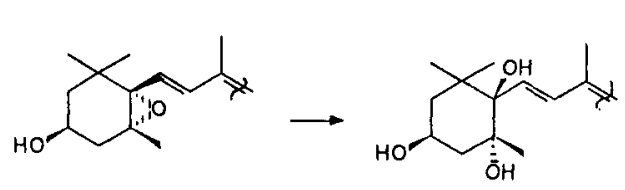

26

27<smiles>C=CC(=O)C=C1C(C)=CC(=O)CC1(C)C</smiles>

21<smiles>C=C(C)C=C[C@@]1(O)[C@H](COC(=O)CC(=C)C#CC2=C(C)CC(O)CC2(C)C)CC(=O)CC1(C)C</smiles><smiles>CC(C#CC1=C(C)CC(O)CC1(C)C)=CC=CC=CC=CC(C)=Cc1cc(C=C[C@H]2C(C)(C)C[C@@H](O)C[C@@]2(C)O)co1</smiles>

$\underline{23}$

\section{Acknowledgements}

Terje Bjørnland, Anne Fiksdahl, Per Foss, sissel hertzberg and Vassilia Partali were the main co-workers in the Trondheim laboratory on the work discussed.

\section{REFERENCES}

1. H. Pfander, Key to Carotenoids, 2. Ed., Birkhäuser, Basel, 1988

2. P. Foss, R.R.L. Guillard and S. Liaaen-Jensen, Phytochem. 25, 119-124 (1986)

3. A. Fiksdahl, T. Bjornland and S. Liaaen-Jensen, Phytochem. $23,649-655$ (1984)

4. T. Bjornland, G. Borch and S. Liaaen-Jensen, phytochem. 25, 201-205 (1986)

5. K. Aareskjold, H. Kayser and S. Liaaen-Jensen, Tetrahedron Letters, 22, 4541-4544 (1981)

6. P. Foss, T. Skjetne and S. Liaaen-Jensen, Acta Chem, Scand. B40, 170-177 (1986)

7. S. Hertzberg, T. Mortensen, G. Borch, H.W. Siegelman and S. Liaaen-Jensen phytochem. $16,587-590$ (1977)

8. S. Isoe, S. Katsamura, S.B. Hyeon and T. Sakan, Tetrahedron Lett. 1089-1092 (1971)

9. K. Bernhard, G.P. Moss, G. Tóth and B.C.I. Weedon, Tetrahedron Lett. 3899-3902 (1974)

10. R. Buchecker, U. Marti and C.H. Eugster, Helv. Chim. Acta 67, 2043-2056 (1984)

11. H. Rønneberg, A.G. Andrewes, G. Borch, R. Berger and S. Líaen-Jensen, Phytochem. 24, $309-319(1985)$

12. P. Foss, O.M. Skuiberg, I. Kilaas and S. Liaaen-Jensen, Phytochem. 25, 1127-1132 (1986)

13. S. Hertzberg, J.E. Johansen, T. Ramdahi, G. Borch and S. Liaaen-Jensen, Biochem. Syst. Ecol. 11，267-275 (1983)

14. V. Partali, Y. Olsen, P. Foss and S. Liaaen-Jensen, Comp. Biochem. Physiol. 82B, 767-772 (1985) 